\title{
Excretion of Neutral $\alpha$-Glucosidase, Determined with a Continuous Assay, and of Acid $\alpha$-Glucosidase in the Urine of Human Reference Subjects
}

\author{
By W. Pape, R. Kochmann, Gabriela Kochmann, M. Blank and K. Baumann \\ Abteilung für Zellphysiologie, Physiologisches Institut der Universität Hamburg
}

(Received September 1, 1981/April 18, 1983)

Summary: The catalytic activities of neutral and acid $\alpha$-glucosidase were selectively determined in human urine. Urinary excretion of neutral and acid $\alpha$-glucosidase in reference subjects was found to be in the range 1.61 to $20.36 \mu \mathrm{kat} / \mathrm{mol}$ creatinine and 7.47 to $33.60 \mu \mathrm{kat} / \mathrm{mol}$ creatinine, respectively. Urinary excretion of both enzymes was not related to sex, age or diuresis. A continuous assay was introduced to improve the determination of neutral $\alpha$-glucosidase.

Bestimmung der Ausscheidung von neutraler $\alpha$-Glucosidase mit einem kontinuierlichen optischen Test und von saurer $\alpha$-Glucosidase im Urin von Referenzpersonen

Zusammenfassung: Die Aktivität von neutraler und saurer $\alpha$-Glucosidase wurde selektiv im menschlichen Urin bestimmt. Im Urin von Referenzpersonen wurde eine Ausscheidung von neutraler $\alpha$-Glucosidase zwischen 1,61 und 20,36 $\mu \mathrm{kat} / \mathrm{mol} \mathrm{Kreatinin}$ und von saurer $\alpha$-Glucosidase $\mathrm{zwischen} 7.47 \mathrm{und} 33,60 \mu \mathrm{kat} / \mathrm{mol}$ Kreatinin gemessen. Die Ausscheidung beider Enzyme war weder geschlechts-, alters- noch diureseabhängig. Zur Optimierung der Bestimmung von neutraler $\alpha$-Glucosidase wird ein kontinuierlicher optischer Test eingeführt.

\section{Introduction}

Human urine contains activities of neutral $\alpha$-glucosidase (EC 3.2.1.20, $\alpha-D$-glucoside glucohydrolase) as well as of acid $\alpha$-glucosidase (EC 3.2.1.3, 1,4- $\alpha$ $D$-glucan glucohydrolase) (1-4). Due to the extremely low activity of both enzymes in human serum (5-9) and to the high molecular weight of $\alpha$ glucosidases $(10-13)$ it is reasonable to assume that neither $\alpha$-glucosidases are filtered to a signiificant extent in the renal glomerulus. The activity of neutral $\alpha$-glucosidase originates from brush border membranes of renal proximal cells (14), whereas acid $\alpha$ glucosidase originates from lysosomes (15). Human urinary excretion of $\alpha$-glucosidase has been measured in control subjects and in patients with various diseases $(1-4,16-28)$.

In the preceding paper we reported optimal test conditions for the selective determination of neutral and acid $\alpha$-glucosidase, using discontinuous assays (29).
In the present investigation we have determined the urinary excretion of both enzymes in 24-h urines of reference subjects. These data may serve as controls for future studies on urinary excretion of neutral and acid $\alpha$-glucosidase in patients. The determination of neutral $\alpha$-glucosidase was improved by introducing a continuous assay.

\section{Materials and Methods}

Reagents

ATP, NADP ${ }^{+}$, hexokinase (ATP: $D$-hexose-6-phosphate phosphotransferase (EC 2.7.1.1)) and glucose-6-phosphate dehydrogenase ( $D$-glucose-6-phosphate: $\mathrm{NADP}^{+}$1-oxidoreductase (EC 1.1.1.49)) were purchased from Boehringer, Mannheim, Germany; bovine serum albumin $(99 \%)$ and $D(+)$-turanose were from SERVA, Heidelberg, Germany, and Multistix ${ }^{\circledR}$ from Miles, Ames Division, Frankfurt/M., Germany, All other chemicals were analytical grade from Merck, Darmstadt, Germany. 


\section{subjects}

To determine the activity of neutral $\alpha$-glucosidase 150 urine samples (collecting period $24 \mathrm{~h}$ ) were studied, including 90 specimens from apparently healthy subjects who were allowed to engage in their normal activities and to maintain their usual fluid intake, except alcohol, and 60 specimens from control patients. $101 \mathrm{spec}-$ imens were collected for the determination of urinary acid $\alpha$-glucbsitlase; 77 §ämplès from apparently healthy subjects and 24 sam-

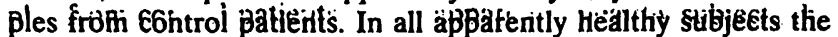
tifihalysis was normal. All control patients were admitted to the hospital for fractures, inguinal hernia, piles or uncomplicated gallstone disease; apart from the current complaint, they were apparently healthy, as judged from physical examination and routine laboratory tests, including serum creatinine determination. No subject had a medlet histofy of metabolic diseases or diseases of the klenies and ufiHáfy tfakt, and nòne was using drugs known to affect enzyme excietion in Ufiñe. ThE age of all subjects ranged between 10 and $8 \hat{2}$ years.

\section{Pretreated urines}

24-h urines were colleeted in polythene bottles containing sodium

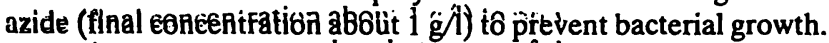
The volume was meassufed and aliquiots of of the native urinês were subjeeted to ufinalysis. $10 \mathrm{ml}$ of native urine were centrifuged at $1300 \hat{g}$ for $5 \mathrm{~min}$ to 'sediment cells and debris. The top $4 \mathrm{ml}$ of urine were mixed with $1 \mathrm{ml}$ bovine serum albumin to achieve an albumin concentration of $2 \mathrm{~g} /$. This sample was concentrated (about 2-fold) by ultrafiltration and subsequently diafiltered using a modified ultrafiltration system (Multi=Mlefo Ultrafiltration System MMCA eonsistiñ g of 8 individual cells supplied with YM 10 Diaflo membranes, both from Amicon, Witten, Germany). Ultrafiltration was Berformed using a pressure of $127: 9 \mathrm{kPa}(1.3$ baf); subsequuên't diafiltration was performed for $30 \mathrm{~min}$ using the şâme pressure and sodium chloride solution $(150 \mathrm{mmol} / \mathrm{l})$ to separate urinary $\alpha$-glucosidase from low molecular weight substances which may interfere with the enzyme determination. After diafiltration the volume of each ultrafilitration cell was stirred for $15 \mathrm{~min}$ to remove slibstanees fetained on the filter. After collection of the pretreated ufine sample, $146.4 \pm 18 . \hat{3} \mu l(\mathrm{~h} \equiv \mathrm{g})$ remained in eagh Eell of the modified ultrafiltration system as dead space. The àverage recovery of the activities of neutral and acid $\alpha=$ glucosidase in this procedure (corrected for dead space) wäs 97.6 $\pm 1.8 \%$ and $97.3 \pm 1.9 \%$, respectively. Albumin concentrations in the cell (befere ultpaffiltration) of less than $1 \mathrm{~g} / \mathrm{showed}$ lower reeveries, albumin concentrations of 2 to $4 \mathrm{~g} /$ showed constant recoveries. Loss of glucose during the procedure was determined using $5 \mathrm{ml}$ samples with added glueఠse $(2 ; 5$ and $100 \mathrm{mmol} / 1)$; 96.9 to $97.7 \%$ of the gluease was rembved: $6.1 \mathrm{mil}$ alliquots of the pretreated urines Wefé used for the determination of neutral or aald $\alpha=$ glucasidasê.

\section{Assays}

\section{Continuous assay for neutral $\alpha$-glucosidase}

To improve our assay for a selective detefminatien of neutral $\alpha$ glucosidase (29), the enzyme activity was assayed in a continuous optical test with hexokinase as auxiliary enzyme and glucose $e_{-}^{-5}$ phosphate dehydrogenase as indicator enzyme (30), according to the following equations:
Tab, 1, Continuous assay of neutral $\alpha$-glucosidase (EC 3.2.1.20).

Final concentrations in the test

Phosphate buffer pH 7.0

Magnesium sulphate

NADP ${ }^{+}$

ATP

Maltose

$D(\neq)=$ Turanose

Hexokinase

Glucose-6-phosphate dehydrogenase

$\begin{array}{cc}80 & \mathrm{mmol} / \mathrm{h} \\ 5 & \mathrm{mmol} / / \\ 2.5 \mathrm{mmol} / \mathrm{h} \\ 2.5 \mathrm{mmol} / / \\ 20 & \mathrm{mmol} / 1 \\ 25 & \mathrm{mmol} / 1 \\ 50 & \mu \mathrm{kat} / 1 \\ 80 & \mu \mathrm{kat} / 1\end{array}$

As shown later in the "Results and Discussion", the following assay conditions were optimal for the continuous assay of neutral $\alpha$ glueosidase (tab. 1). The enzyme reactions were started by the additioñ of a $0.1 \mathrm{ml}$ aliquot of a pretreated urine sample to $0.9 \mathrm{ml}$ reagent mixture. The time-dependent changes in NADPPH absorbance at $334 \mathrm{~nm}$ at $25^{\circ} \mathrm{C}$ were registered automatically in interväls of 3 min with an Eppendorf Digitalphotometer 6118 fitted with cuvette changer 2705 and printer 6522 (Eppendorf Gerätebau Netheler \& Hinz, Hamburg, Germany), or with a PMQ 3 Photometer (Zeiss, Oberkochen, Germany) connected to a Mẽtfawatt RE 511 recorder. Pretreated urine samples were measured in triplictate : Three blank samples $(1.50 \mathrm{mmol} / \mathrm{l}$ sodium chloride containing $2 \mathrm{~g} / \mathrm{l}$ bovine serum albumin) were used as controls, and in all determinations the absorbance of the reagent mixture was registered for two $10 \mathrm{~s}$ periods before the addition of the $0.1 \mathrm{ml}$ samples. After the lag phase, at least three time-dependent changes in NADPH absorbance were used to calculate the activities of neutral $\alpha$-glucosidase, expressed in nmoles maltose hydro= lysed per second per liter (nkat/l) according to the following equation:

Catalytic activity concentration

$$
\begin{aligned}
& =\frac{1}{2} \times \frac{\Delta A}{\Delta t} \times \frac{v_{2} \times 1.25}{v_{1}} \times \frac{V}{\varepsilon \times L \times v} \\
& =\frac{\Delta A}{3 \min } \times \frac{v_{2} \times 1.25}{v_{1}} \times 4494.8[\text { nkat } / 1],
\end{aligned}
$$

where $\Delta \mathbf{A} / \Delta t$ is the change in absorbance pert time interval between two measurements; since 2 mol glucose are liberated per 1 mol maltose the absorbance must be divided by $2 ; \frac{v_{2} \times 1.25}{v_{1}}$ is the urine pretreatment factor $\left(v_{1}\right.$ is the volume in the ultrafiltration cell before ultrafiltration, $v_{2}$ is the volume in the ultrafiltration cell after ultrafiltration and diafiltration and 1.25 is the urine sample dilution factor caused by mixing with albumin solution); $\mathrm{V}$ is the reaction volume in the cuvette $(1.0 \mathrm{ml}), \varepsilon$ is the molar lineic absorbance $\left(618 \mathrm{~m}^{2} \times \mathrm{mol}^{-1}\right), \mathrm{L}$ is the pathlength of the cuvette $(0.01 \mathrm{~m})$ and $v$ is the aliquiot of pretreated urine sample used $(0.1 \mathrm{ml})$.

The urinary activity of $\alpha$-glucosidase was expressed in nkat/24 h and in $\mu \mathrm{kat} / \mathrm{mol}$ urinary creatinine.

The reagent mixture for the continuous assay of neutitral $\alpha$-gluçosidasi is stable for at least 3 days at $4^{\circ} \mathrm{C}$.

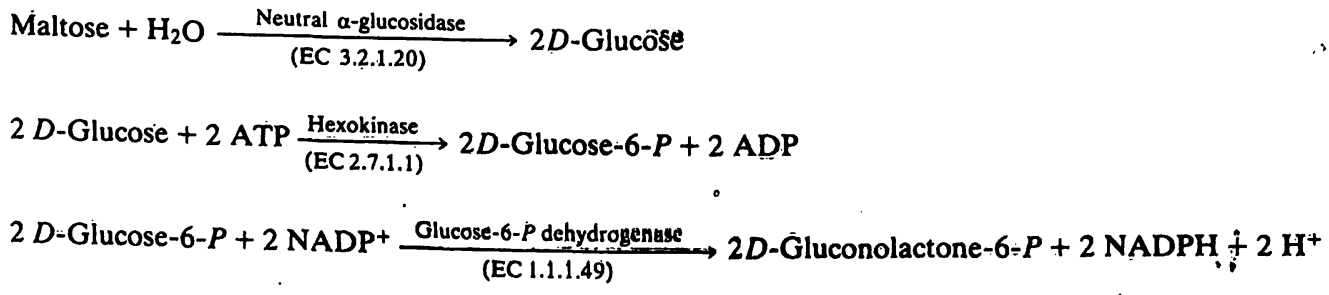

J. Clin. Chem. Clin. Bịochem. / Vol. 21, 1983 / Na. 8 
The activity of acid $\alpha$-glucosidase was determined by a two point method (29). Creatinine concentration was measured enzymatically (31) and urinary protein concentration was determined with bovine serum albumin as the standard (32).

\section{Statistics}

Data on urinary excretion of neutral and acid $\alpha$-glucosidase revealed a lognormal distribution according to the fractile graphical analysis (33). Using logarithmically transformed values, normal limits $(2.5,50$ and 97.5 percentiles) were calculated. Sex-related differences in our experimental data were evaluated using the ttest for heterogeneous variances, and age-related differences were evaluated by calculating the coefficient of linear correlation.

\section{Results and Discussion}

Continuous assay of neutral $\alpha$-glucosidase

By using discontinuous assays we have achieved selectivity for the determination of neutral and acid $\alpha-$ glucosidase (29). Several advantages such as rapidity and accuracy led us to the development of the continuous assay for neutral $\alpha$-glucosidase described in this paper. The activity of neutral $\alpha$-glucosidase was highest at $\mathrm{pH} 7.0$ to 7.2 (fig. 1) in a phosphate buffer at a concentration of $80 \mathrm{mmol} / \mathrm{l}$ (fig. 2). The catalytic rate of reaction showed saturation at ATP and $\mathrm{NADP}^{+}$concentrations of $1.5 \mathrm{mmol} / \mathrm{l}$ (fig. 3). ATP and $\mathrm{NADP}^{+}$were used at somewhat higher concentration $(2.5 \mathrm{mmol} / \mathrm{l})$ in the test. To determine an optimal concentration for the auxiliary and indicator enzymes, absorbance differences were measured at varying hexokinase activity concentrations (15 to 80 $\mu \mathrm{kat} / \mathrm{l})$ at a glucose-6-phosphate dehydrogenase activity concentration of $40 \mu \mathrm{kat} / \mathrm{l}$; and at varying glucose-6-phosphate dehydrogenase activity concentrations (15 to $80 \mu \mathrm{kat} / \mathrm{l})$ at a hexokinase activity concentration of $40 \mu \mathrm{kat} / \mathrm{l}$. Under these conditions the reaction rate was constant, but the lag phase increased with decreasing catalytic concentrations of glucose-6-phosphate dehydrogenase. Therefore a hexokinase activity concentration of $50 \mu \mathrm{kat} / 1$ and a glucose-6-phosphate dehydrogenase activity concentration of $80 \mu \mathrm{kat} / \mathrm{l}$ was chosen. The relation between the activity of neutral $\alpha$-glucosidase and substrate turnover was linear (fig. 4) in the range from 1 to $2000 \mathrm{nkat} / \mathrm{l}$. The reaction rate was proportional to the $\alpha$-glucosidase concentration. The lag phase decreased slightly with increasing $\alpha$-glucosidase concentration. The average lag phase was $2.48 \pm 0.84$ $\min (n=28)$. A linear relation was also found by comparing the results of the discontinuous and the continuous method with a somewhat higher recovery of $106.2 \pm 7.5 \%$ for the latter (fig. 5). Using the continuous assay, the $K_{\mathrm{m}}$-value of neutral $\alpha$-glucosi-

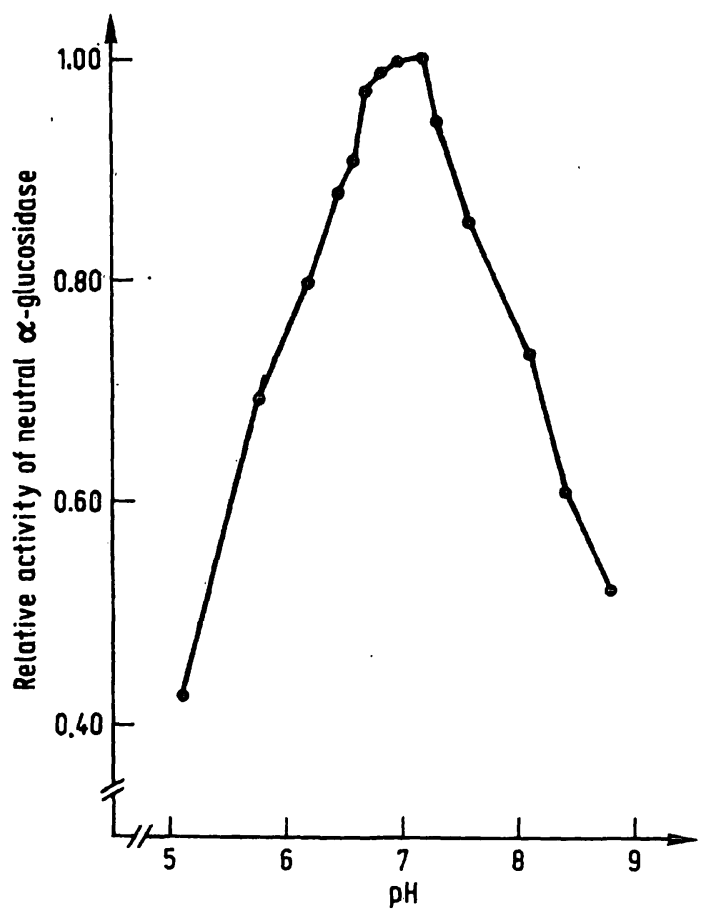

Fig. 1. Relative activity of neutral $\alpha$-glucosidase as a function of pH. All other conditions were held constant.

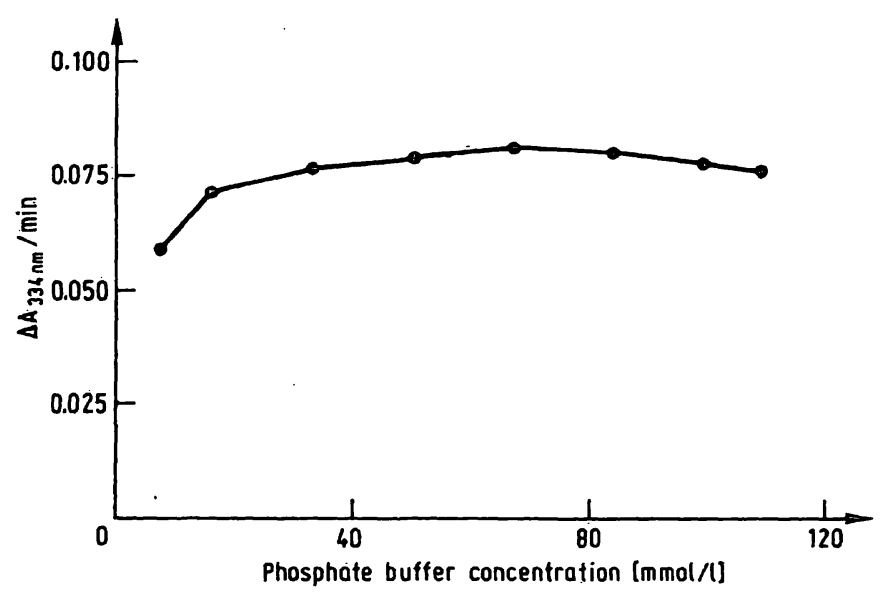

Fig. 2. Rate of change of absorbance as a function of phosphate buffer concentration. All other conditions were held constant.

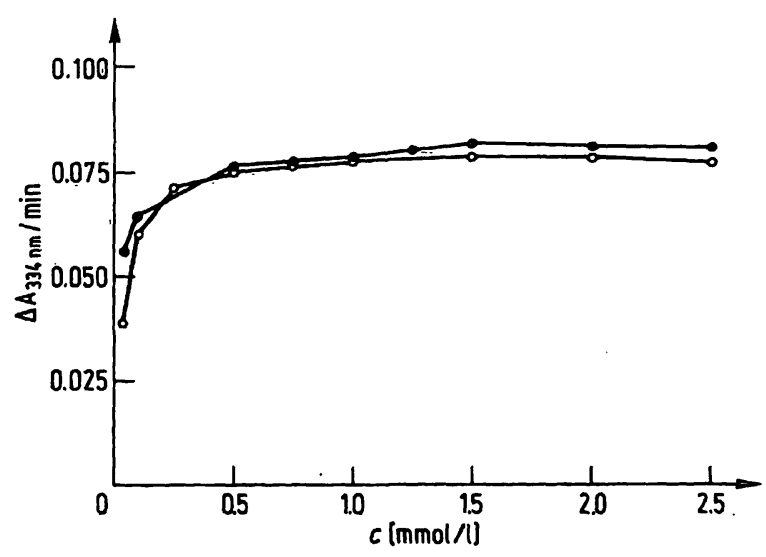

Fig. 3. Rate of changes of absorbance as a function of ATP $(\mathrm{O}-\mathrm{O})$ concentration at a NADP ${ }^{+}$concentration of 1.5 $\mathrm{mmol} / \mathrm{h}$ and as a function of $\mathrm{NADP}^{+}\left(\mathrm{O}_{-}-\mathrm{O}\right)$ concentration at an ATP concentration of $1.5 \mathrm{mmol} /$. All other conditions were held constant. 


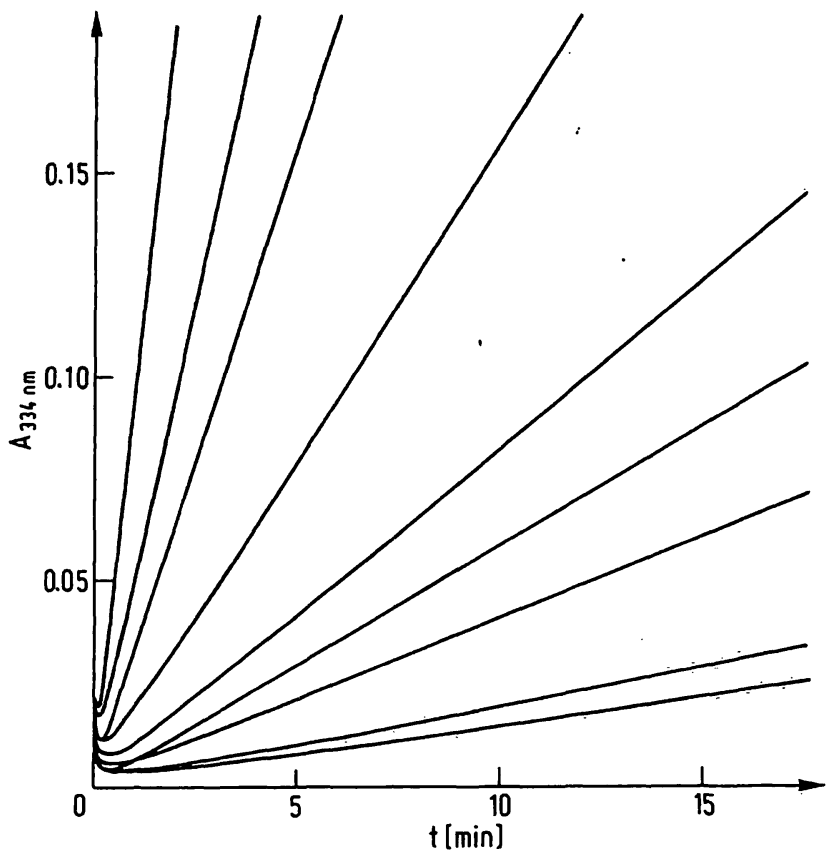

Fig. 4. Original graphs of absorbance as a function of time measured at various catalytic activity concentrations of $\alpha$-glucosidase $(1360,680,453,227,110,80,55,26$ and 18.5 nkat/1). All other conditions were held constant, except that measurements were performed at $37^{\circ} \mathrm{C}$.

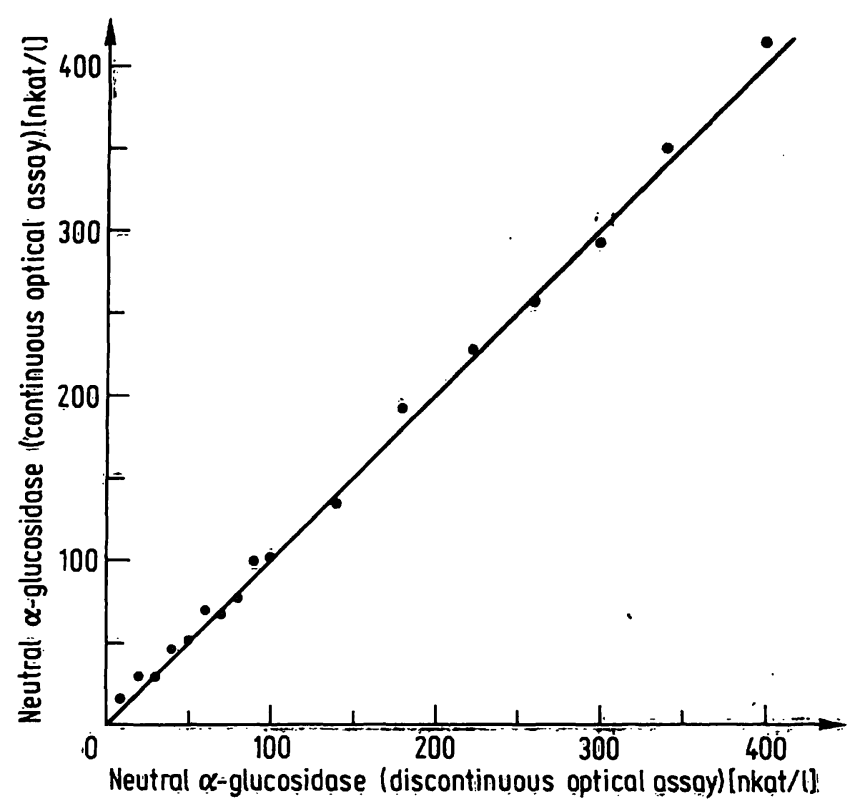

Fig. 5. Comparison of measurementi of catalytic activity concentrations of neutral $\alpha$-glucosidase performed by continuouis and discontinuous optical assay, - regression line $\mathbf{y}=\dot{x}$.

Tab. 2. Statistical evaluation of the urinary excretion of neutral $\alpha$-glucosidase in female and male healthy subjects ${ }^{a}$ ) and control patients $\left.^{b}\right)$. Estimates of normal limits $(2.5,50$ and 97.5 percentiles) and ranges are given for: enzyme catalytic concentration, enzyme excretion per $24 \mathrm{~h}$ and per mol creatinine, urine volume per time and creatinine concentration.

\begin{tabular}{|c|c|c|c|c|c|c|}
\hline & \multirow[t]{2}{*}{ Sex } & \multicolumn{3}{|c|}{ Percentiles } & \multirow[t]{2}{*}{ Range } & \multirow[t]{2}{*}{ Unit } \\
\hline & & 2.5 & 50 & 97.5 & & \\
\hline \multicolumn{7}{|c|}{ Healthy subjects } \\
\hline \multirow[t]{3}{*}{ Neutral $\alpha$-glucosidase } & $\begin{array}{l}q \\
\delta\end{array}$ & $\begin{array}{l}15.7 \\
20.7\end{array}$ & $\begin{array}{l}48.7 \\
59.6\end{array}$ & $\begin{array}{l}151 \\
171\end{array}$ & $\begin{array}{r}13.3-178 \\
8.7-178\end{array}$ & nkat/l \\
\hline & $\begin{array}{l}q \\
\delta\end{array}$ & $\begin{array}{l}20.0 \\
26.1\end{array}$ & $\begin{array}{l}54.0 \\
75.1\end{array}$ & $\begin{array}{l}146 \\
216\end{array}$ & $\begin{array}{ll}16.8 & -195 \\
13.0 & -213\end{array}$ & nkat $/ 24 \mathrm{~h}$ \\
\hline & $\begin{array}{l}q \\
\delta\end{array}$ & $\begin{array}{l}1.82 \\
2.06\end{array}$ & $\begin{array}{l}5.00 \\
5.83\end{array}$ & $\begin{array}{l}13.69 \\
16.74\end{array}$ & $\begin{array}{l}1.81-12.22 \\
1.61-20.36\end{array}$ & $\begin{array}{l}\mu \mathrm{kat} / \mathrm{mol} \\
\text { créatinine }\end{array}$ \\
\hline Urine volume & $\begin{array}{l}q \\
\delta\end{array}$ & $\begin{array}{l}0.56 \\
0.59\end{array}$ & $\begin{array}{l}1.11 \\
1.30\end{array}$ & $\begin{array}{l}2.20 \\
2.72\end{array}$ & $\begin{array}{ll}0.60- & 2.20 \\
0.40- & 2.30\end{array}$ & $1 / 24 h$ \\
\hline Creatinine & $\frac{q}{\delta}$ & $\begin{array}{l}4.60 \\
4.77\end{array}$ & $\begin{array}{r}9.81 \\
10.25\end{array}$ & $\begin{array}{l}20.86 \\
22.28\end{array}$ & $\begin{array}{l}3.98-17.86 \\
4.77-23.69\end{array}$ & $\mathrm{mmol} / \mathrm{h}$ \\
\hline \multicolumn{7}{|c|}{ Control patients } \\
\hline \multirow[t]{3}{*}{ Neutral $\alpha$-glucosidase } & $\begin{array}{l}q \\
\delta\end{array}$ & $\begin{array}{l}15.8 \\
16.8\end{array}$ & $\begin{array}{l}50.7 \\
56.6\end{array}$ & $\begin{array}{l}162 \\
190\end{array}$ & $\begin{array}{l}13.3-152 \\
19.3-221\end{array}$ & nkat/l \\
\hline & $\begin{array}{l}q \\
\delta\end{array}$ & $\begin{array}{l}24.3 \\
18.9\end{array}$ & $\begin{array}{l}63.5 \\
72.3\end{array}$ & $\begin{array}{l}167 \\
277\end{array}$ & $\begin{array}{ll}23.3 & -113 \\
10.7 & -213\end{array}$ & nkat $/ 24 \mathrm{~h}$ \\
\hline & $\begin{array}{l}q \\
0\end{array}$ & $\begin{array}{l}2.65 \\
2.68\end{array}$ & $\begin{array}{l}6.88 \\
6.62\end{array}$ & $\begin{array}{l}17.87 \\
16.29\end{array}$ & $\begin{array}{l}2.68-12.78 \\
2.15-13.35\end{array}$ & $\begin{array}{l}\mu \mathrm{kat} / \mathrm{mol} \\
\text { creatinine }\end{array}$ \\
\hline Urine volume & $\begin{array}{l}q \\
\delta\end{array}$ & $\begin{array}{l}0.64 \\
0.65\end{array}$ & $\begin{array}{l}1.25 \\
1.34\end{array}$ & $\begin{array}{l}2.46 \\
2.66\end{array}$ & $\begin{array}{ll}0.70- & 2.15 \\
0.55- & 2.15\end{array}$ & $1 / 24 \mathrm{~h}$ \\
\hline Creatinine & $\begin{array}{l}q \\
\delta\end{array}$ & $\begin{array}{l}4.60 \\
3.89\end{array}$ & $\begin{array}{l}7.34 \\
8.66\end{array}$ & $\begin{array}{l}24.58 \\
19.54\end{array}$ & $\begin{array}{l}4.42=19.27 \\
3.54-16.80\end{array}$ & $\mathrm{mmol} / \mathrm{h}$ \\
\hline
\end{tabular}

a) 90 healthy subjects, 50 males with a mean age of 36 years, 40 females with a mean age of 41 years.

b) 60 control patients, 34 males with a mean age of 42 years, 26 females with a mean age of 59 years. 
dase for maltose $\left(K_{\mathrm{m}}=0.67 \mathrm{mmol} / \mathrm{l}\right)$ and the inhibitor constant for turanose $\left(K_{1}=5.2 \mathrm{mmol} / \mathrm{l}\right)$ were determined. Both constants and the type of inhibition (competitive) are in agreement with those obtained by the discontinuous assay (29).

The within-run precision of our continuous method was assayed by a series of 20 determinations of the activity of neutral $\alpha$-glucosidase of the same specimen. The mean value was $109.5 \mathrm{nkat} / \mathrm{l}$, with a coefficient of variation of $2.1 \%( \pm 2.3 \mathrm{nkat} / \mathrm{1})$. The dayto-day precision was studied for 10 days by repeated analysis of aliquots of the same specimen. The coefficient of variation was $4.4 \%$.

Albumin concentrations up to $8 \mathrm{~g} / 1$ in pretreated urine samples had no effect on the determination of neutral $\alpha$-glucosidase. Glucose concentrations up to $1.5 \mathrm{mmol} / 1$ affected only the lag phase in pretreated urine samples.

The activity of neutral $\alpha$-glucosidase is inhibited by turanose, potassium ions, tris and erythritol (see 1.c. (29)). In the discontinuous assay for neutral $\alpha$-gluc- osidase (29) and in the continuous assay described here, turanose has no effect on the activity of neutral $\alpha$-glucosidase, but inhibits almost completely the residual activity of acid $\alpha$-glucosidase (29).

Neutral as well as acid $\alpha$-glucosidase were found to be stable for several days at $4{ }^{\circ} \mathrm{C}$ and even at room temperature in native urine samples. Three urine samples stored at $-20^{\circ} \mathrm{C}$ for as long as 6 months showed less than $10 \%$ loss of activity of neutral and acid $\alpha$-glucosidase, respectively.

Urinary excretion of neutral and acid $\alpha$ glucosidase

Urinary excretion of activities of neutral as well as acid $\alpha$-glucosidase in female and male healthy subjects and control patients, estimates of normal limits and ranges and experimental details are compiled in table 2 and 3 . No statistically significant differences could be detected, except that urinary excretion of both enzymes per $24-h$ is higher in men than in

Tab. 3. Statistical evaluation of the urinary excretion of acid $\alpha$-glucosidase in female and male healthy subjects ${ }^{a}$ ) and control patients $\left.{ }^{b}\right)$. Estimates of normal limits (2.5, 50 and 97.5 percentiles) and ranges are given for: enzyme concentration, enzyme excretion per $24 \mathrm{~h}$ and per mol creatinine, urine volume per time and creatinine concentration.

$\begin{array}{cccccc}\text { Sex } & \text { Percentiles } & & & \text { Range } & \text { Unit } \\ & 2.5 & 50 & 97.5 & & \end{array}$

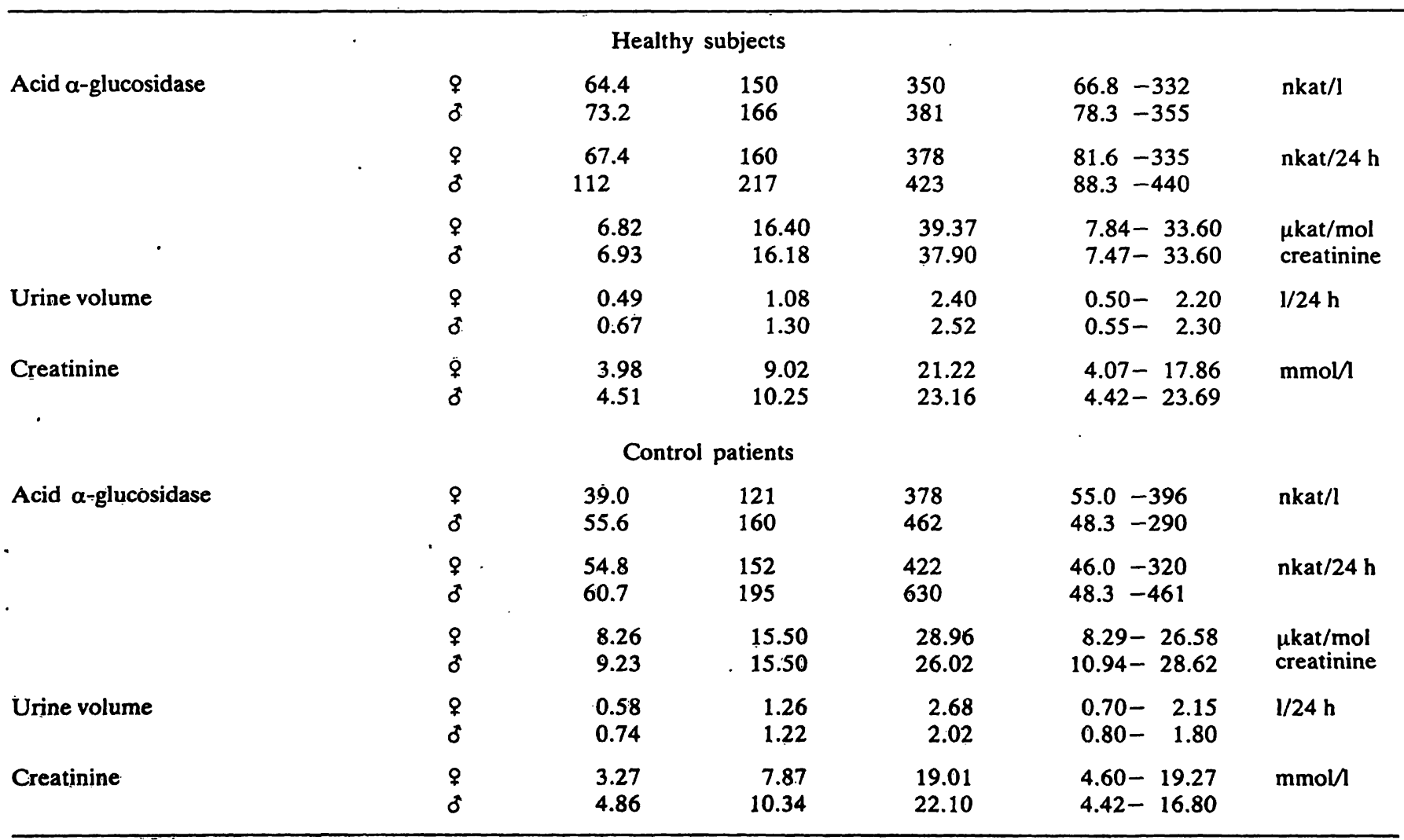

a) 77 healthy subjects, 41 males with a mean age of 41 years, 36 females with a mean age of 47 years.

b) 24 control patients, 10 males with a mean age of 46 years, 14 females with a mean age of 58 years.

J. Clin. Chem. Clin. Biochem. / Vol. 21, 1983 / No. 8 
women in both healthy subjects and control patients. The same sex-related difference in urinary excretion of both enzymes was also found $(P<0.001)$ when both groups of healthy subjects and control patients were taken together. At all levels tested urinary excretion of both $\alpha$-glucosidases was not related to age or diuresis. Thus for the evaluation of urinary excretion of both $\alpha$-glucosidases, females and males of both groups of healthy subjects and control patients were taken together to represent the reference group, and the urinary excretion was considered exclusively in $\mu$ kat per mol urinary creatinine. These reference subjects excreted renal brush border neutral $\alpha$-glucosidase in a relatively small range from 1.61 to $20.36 \mu \mathrm{kat} / \mathrm{mol}$ creatinine $(\mathrm{n}=150)$ and renal lysosomal acid $\alpha$-glucosidase in a somewhat broader range from 7.47 to $33.60 \mu \mathrm{kat} / \mathrm{mol}$ creatinine $(n=101)$. Statistical data are compiled in table 4 .

Tab. 4. Statistical evaluation of the urinary excretion of neutral $\alpha$-glucosidase' per mol creatinine for all subjects investigated of both sexes (150 control subjects) and the corresponding values for acid $\alpha$-glucosidase (101 control subjects). Estimates of normal limits (2.5, 50 and 97.5 percentiles) and ranges are given.

Percentiles

2.5

Neutral $\alpha$-glucosidase ( $\mu \mathrm{kat} / \mathrm{mol}$ creatinine)
2.17
5.93
16.20
$1.61-20.36$

Acid $\alpha$-glucosidase ( $\mu \mathrm{kat} / \mathrm{mol}$ creatinine)

7.25

15.97

35.67

$7.47-33.60$
Intra-individual comparison of the excreted activities of neutral and acid $\alpha$-glucosidase showed that the activity of acid $\alpha$-glucosidase was always higher than that of neutral $\alpha$-glucosidase $(n=79)$. The most frequent ratio was between 2 and 3 , with an asymmetric distribution characterized by the following normal limits: ratio 1.2 (2.5 percentile); ratio 2.9 (50 percentile), and ratio 6.7 (97.5 percentile).

The day-to-day variation of urinary excretion of neutral and acid $\alpha$-glucosidase per mol urinary creatinine was very small, i.e. 7.5 and $6.5 \%$, respectively. Diurnal variations in the urinary excretion of neutral and acid $\alpha$-glucosidase was observed throughout a 24-h period by collecting urine at 3-h intervals. As shown earlier for the urinary $\alpha$-glucosidase excretion measured at $\mathrm{pH} 5.0(24)$, the urinary excretion of neutral and acid $\alpha=$ glucosidase was. high between $3 \mathrm{a} . \mathrm{m}$. and $9 \mathrm{a} . \mathrm{m}$. and low during the afternoon and evening. Thus urines for the determination of both $\alpha$-glucosidases should be collected at fixed time intervals, preferably during a 24-h period.

\section{Acknowledgements}

Part of these studies was performed in partial fulfilment of the requirements for the M.D. degiree by $R$. Kochmann.

The excellent technical assistance of Mrs. K. Berndt and Mrs. $B$. Lutteroth is appreciated. Preliminary notes on this work have appeared in abstract form (34-36). These studies were supported by the Deutsche Forschungsgemeinsischaft $\mathrm{Ba} 271 / 6$.

\section{References}

1. Franzini, C. \& Bonini, P. A. (1967) Clin. Chim. Acta 17, 505-510.

2. Salafsky, I. S. \& Nadler, H. L. (1973) J. Pediatr. 82, 294297.

3. Mehler, M. \& Di Mauro, S. (1976) Transaction Am. Neurol. Assoc. $101,172-173$.

4. Soyama, K., Ono, E., Shimada, N., Tanaka, K. \& Kusunoki, T. (1977) Clin. Chim. Acta 77, 61-67.

5. Adlung, J. (1969) Z. Gastroenterologie 7, 402-406.

6. Gamklou, R. \& Schersten, T. (1973) Scand. J. Clin. Lab. Invest. $31,21-26$.

7. Soyama, K., Ono, E. \& Shimada, N. (1977) J. Kyoto Pref. Univ. Med. 86, 453-460.

8. Annunziata, P. \& di Matteo, G. (1978) Clin. Chim. Acta 90 , 101-106.

9. Griffiths, P. A., Milsom, J. P. \& Lloyd, J. B. (1978) Clin. Chim. Acta 90, 129-141.

10. Auricchio, F., Bruni, C. B. \& Sica, V. (1968) Biochem. J. 108, 161-167.

11. Bruni, C. B., Auricchio, F. \& Covelli, I. (1969) J. Biol. Chem. 244, 4735-4742.
12. Jeffrey, P. L., Brown, D. H. \& Brown, B. I. (1970) Biochemistry $9,1403-1415$.

13. de Burlet, G., Vannier, Ch., Giudicelli, J. \& Sudaka, P. (1979) Biochimie 61, 1177-1183.

14. Berger, S. J. \& Sacktor, B. (1970) J. Cell Biol. 47, 637-645.

15. Lejeune, N., Thines-Sempoux, D. \& Hers, H. G. (1963) Biochem. J. 86, 16-21.

16. Fleury, P. F., Courtois, J. E. \& Ramon, D. (1951) Bull. Soc. Chim. Biol. 33, 1762-1767.

17. Bonini, P. A. \& Franzini, C. (1968) Biochim. Biol. Sper. 7, 47-52.

18. Bonini, P. A., Ceriotti, G. \& Franzini, C. (1970) Clin. Chim. Acta 27, 415-419.

19. Campanacci, L., Guarnieri, G. F., Faccini, L., Bellini, G. \& Carretta, R. (1975) Minerva Nefrol. 22, 155-168.

20. Bomback, F. M., Nakagawa, S., Kumin, S. \& Nitowsky, H. M. (1976) Diabetes 25, 420-427.

21. Maruhn, D., Fuchs, I., Mues, G. \& Bock, K. D. (1976) Clin. Chem. 22, 1.567-15.74.

22. Wilhelm, G. \& Peters, J. E. (1976) Z. M̄ed. Labortechnik 17, $155-162$. 
23. Burchard, U., Peters, J. E., Neef, L., Thulin, H., Gründig, C. A. \& Haschen, R. J. (1977) Z. Med. Labor.-Diagn. 18, 190-212.

24. Maruhn, D. Strozyk, K., Gielow, L. \& Bock, K. D. (1977) Clin. Chim. Acta 75, 427-433.

25. Soyama, K. Ono, E., Shimada, N., Tanaka, K. \& Kusunoki, T. (1978) J. Kyoto Pref. Univ. Med. 87, 940-944.

26. Guarnieri, G. F., Faccini, L., Beltram, E., Chersicla, M., Battilana, G., Branchini, B., Ferrara, P., Micheli, W., Lin, S. \& Campanacci, L. (1978) In: Enzymes in health and disease (Goldberg, D. M. \& Wilkinson, J. H., eds.) pp. 186-192, Karger, Basel.

27. Guarnieri, G. F., Faccini, L., Beltram, E., Chersicla, M., Ianche, M., Lin, S. \& Bazzocchi, M. (1979) In: Clinical enzymology symposia (Burlina, A. \& Galzigna, L., eds.) pp. 579600 , Piccin Medical Books, Padua.

28. Maruhn, D. (1979) In: Diagnostic significance of enzymes and proteins in urine (Dubach, U. C. \& Schmidt, U., eds.) pp. 135-145, Hans Huber Publishers, Bern.

29. Kochmann, G., Kochmann, R., Pape, W., Blank, M. \& Baumann, K. (1983) J. Clin. Chem. Clin. Biochem. 21, 503-509.
30. Bergmeyer, H. U., Bernt, E., Schmidt, F. \& Stork, H. (1974) In: Methoden der enzymatischen Analyse (Bergmeyer, H. U., ed.) 3. Aufl., Bd. 2, 1241-1246, Verlag Chemie, Weinheim/Bergstr.

31. Wahlefeld, A. W., Holz, G. \& Bergmeyer, H. U. (1974) In: Methoden der enzymatischen Analyse (Bergmeyer, H. U., ed.) 3. Aufl., Bd. 2, 1834-1838, Verlag Chemie, Weinheim/ Bergstr:

32. Schacterle, G. R. \& Pollack, R. L. (1973) Anal. Biochem. 51, 654-655.

33. Linder, A. \& Czegledy, P. (1973) Indian J. Statistics: Series B, 35, 1-14.

34. Kochmann, G., Kochmann, R., Pape, W. \& Baumann, K. (19.80) J. Clin. Chem. Clin. Biochem. 18, 685 (abstract).

35. Kochmann, G., Kochmann, R., Willenbockel, Ch. \& Baumann, K. (1980) Kidney Int. 17, 409 (abstract).

36. Willenbockel, Ch., Franzen-Sieveking, M. \& Baumann, K. (1980) Kidney Int. 17, 418 (abstract).

\section{Dr. W. Pape}

Abteilung für Zellphysiologie

Physiologisches Institut der Universität Hamburg

Grindelallee 117

D-2000 Hamburg 13 
